Images in...

\title{
Insufficiency fractures of the sacrum
}

Dorien Joosen, Marie-Cecile Jacobs, Ron de Nijs

Maxima Medical Centre, Eindhoven, The Netherlands

Correspondence to Dorien Joosen, dorien.joosen@hotmail.com

\section{DESCRIPTION}

We describe a case of three middle-aged women with acute-onset low back pain. Clinical examination was not contributory. Plain radiographs of the pelvis were normal in two patients (figures 1 and 2) and showed signs of sacroiliitis in one patient (figure 3). Subsequently, we performed MRI, which revealed unilateral insufficiency fractures of the sacrum in all patients (figures 4-6).

Insufficiency fractures of the sacrum occur when normal stresses are placed on bones with reduced mineral content and elastic resistance. ${ }^{1}$ Most fractures occur in older patients, especially women. Predisposing factors include osteoporosis, rheumatoid arthritis, prolonged glucocorticoid treatment, pelvic radiotherapy and metabolic bone diseases. Clinical presentation is not specific and highly variable. ${ }^{12}$

Plain radiographs are usually not diagnostic because sacral lesions are often obscured by bowel gas. ${ }^{2}{ }^{3}$ Bone scintigraphy is a sensitive technique, but the classical H-sign, consisting of fractures of both the sacral ala and a horizontal fracture of the sacral body, is present in only $32 \%$ of scintigraphies. ${ }^{3}$ Because of various incomplete patterns, it is difficult to distinguish fractures from sacroiliitis, osteomyelitis or metastatic bone disease. MRI is sensitive to changes in signal from bone marrow oedema that results from

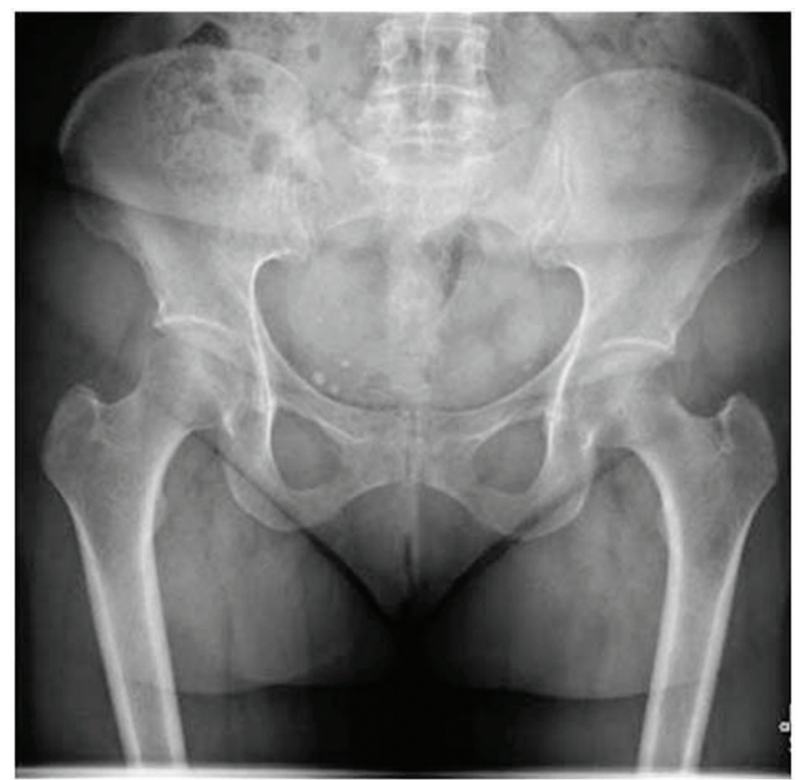

Figure 1 Plain radiograph of patient 1.

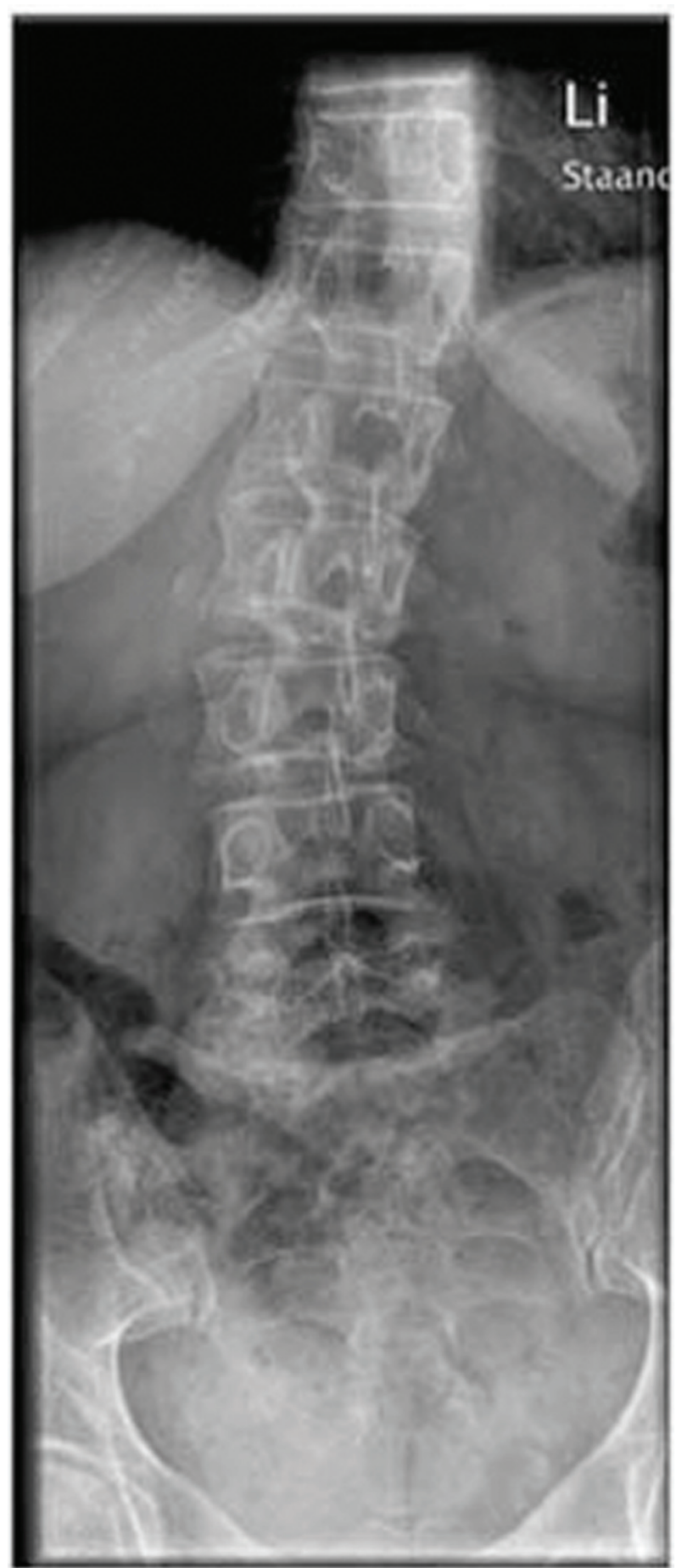

Figure 2 Plain radiograph of patient 2. 


\section{BMJ Case Reports}

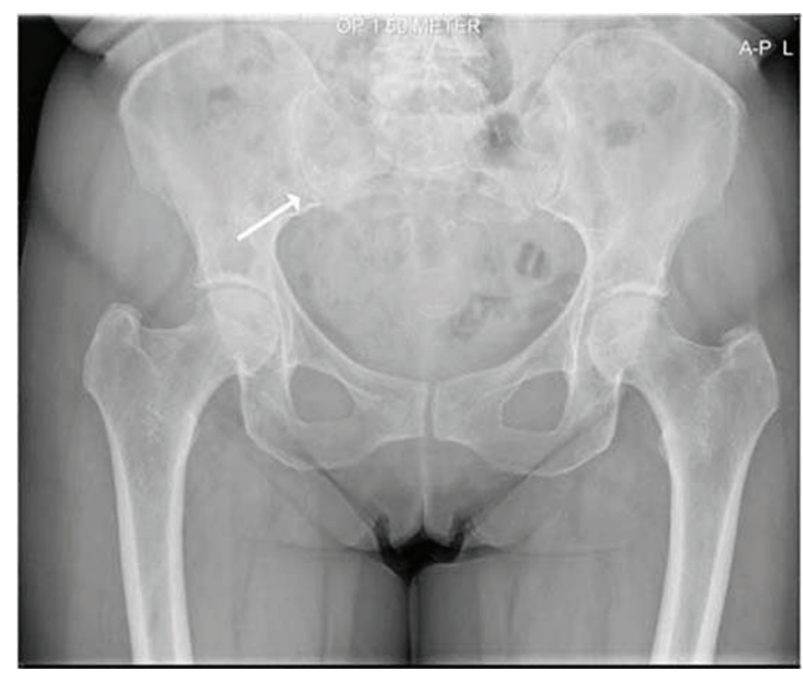

Figure 3 Plain radiograph of patient 3 showing signs of sacroiliitis on the right site.

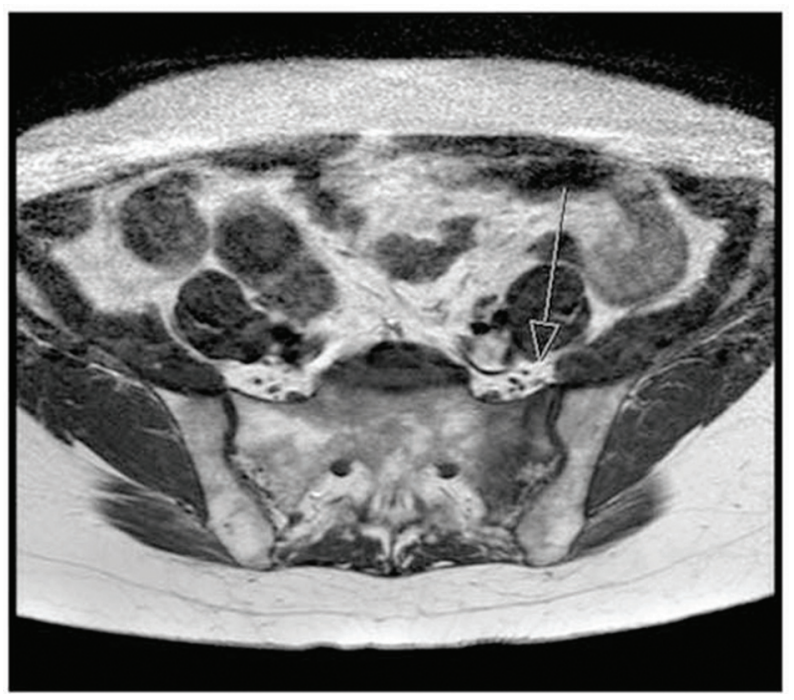

Figure $4 \quad \mathrm{MRI}$ image of patient 1 showing an unilateral (left) insufficiency fracture of the sacrum.

sacral fractures. ${ }^{12}$ These changes in signal are, however, not specific and the lesions can be misinterpreted as metastatic disease. ${ }^{2}{ }^{3}$ CT may be helpful in confirming the diagnosis and can exclude inflammatory and malignant processes. ${ }^{2} 3$ In our three patients, diagnosis could be made by MRI.

Competing interests None.

Patient consent Obtained.

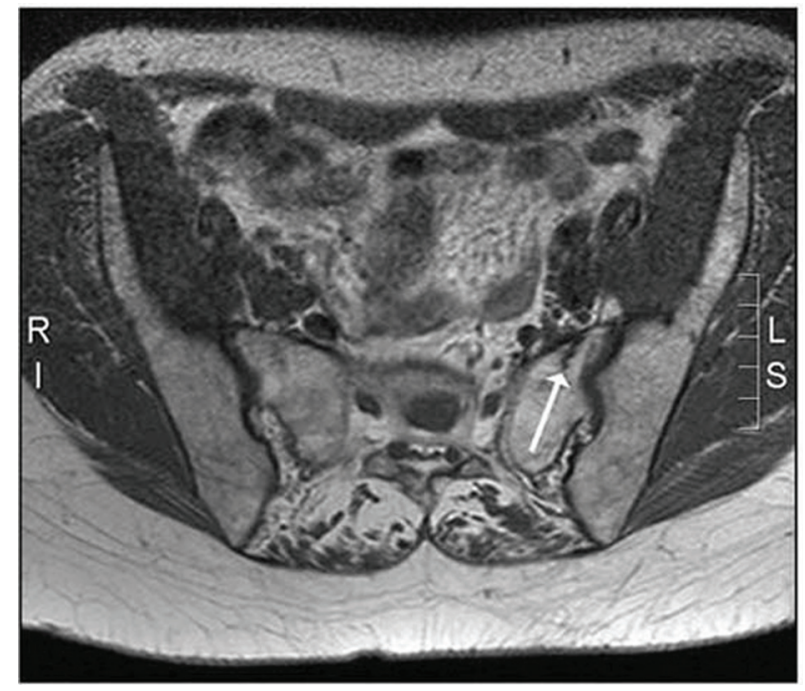

Figure 5 MRI image of patient 2 showing an unilateral (left) insufficiency fracture of the sacrum.

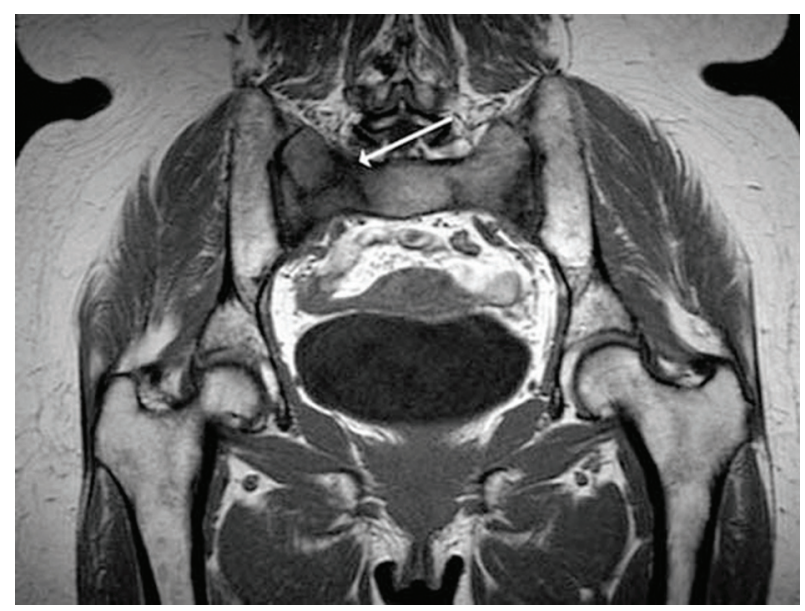

Figure $6 \mathrm{MRI}$ image of patient 3 showing an unilateral (right) insufficiency fracture of the sacrum.

\section{REFERENCES}

1. Tsiridis E, Upadhyay N, Giannoudis PV. Sacral insufficiency fractures: current concepts of management. Osteoporos Int 2006;17:1716-25.

2. Blake SP, Connors AM. Sacral insufficiency fracture. Br J Radiol 2004;77:891-6.

3. Schindler OS, Watura R, Cobby M. Sacral insufficiency fractures. J Orthop Surg (Hong Kong) 2007;15:339-46. 


\section{BMJ Case Reports}

This pdf has been created automatically from the final edited text and images.

Copyright 2011 BMJ Publishing Group. All rights reserved. For permission to reuse any of this content visit http://group.bmj.com/group/rights-licensing/permissions.

BMJ Case Report Fellows may re-use this article for personal use and teaching without any further permission.

Please cite this article as follows (you will need to access the article online to obtain the date of publication).

Joosen D, Jacobs MC, Nijs R. Insufficiency fractures of the sacrum. BMJ Case Reports 2011;10.1136/bcr.12.2010.3630, date of publication

Become a Fellow of BMJ Case Reports today and you can:

- Submit as many cases as you like

- Enjoy fast sympathetic peer review and rapid publication of accepted articles

Access all the published articles

- Re-use any of the published material for personal use and teaching without further permission

For information on Institutional Fellowships contact consortiasales@bmjgroup.com

Visit casereports.bmj.com for more articles like this and to become a Fellow 